\title{
Endoscopic rendez-vous after damage control surgery in treatment of retroperitoneal abscess from perforated duodenal diverticulum: a techinal note and literature review
}

\author{
Ivan Barillaro ${ }^{1}$, Veronica Grassi ${ }^{1,6^{*}}$, Angelo De Sol', Claudio Renzi ${ }^{2}$, Giovanni Cochetti ${ }^{3}$, Francesco Barillaro ${ }^{3}$, \\ Alessia Corsi ${ }^{2}$, Alban Cacurri ${ }^{1}$, Adolfo Petrina ${ }^{4}$, Lucio Cagini ${ }^{5}$, Carlo Boselli ${ }^{2}$, Roberto Cirocchi ${ }^{1}$ and Giuseppe Noya ${ }^{2}$
}

\begin{abstract}
Introduction: The duodenum is the second seat of onset of diverticula after the colon. Duodenal diverticulosis is usually asymptomatic, but duodenal perforation with abscess may occur.

Case presentation: Woman, 83 years old, emergency hospitalised for generalized abdominal pain. On the abdominal tomography in the third portion of the duodenum a herniation and a concomitant full-thickness breach of the visceral wall was detected. The patient underwent emergency surgery. A surgical toilette of abscess was performed passing through the perforated diverticula and the Petzer's tube drainage was placed in the duodenal lumen; the duodenostomic Petzer was endoscopically removed 4 months after the surgery.

Discussion: A review of medical literature was performed and our treatment has never been described.

Conclusion: For the treatment of perforated duodenal diverticula a sequential two-stage non resective approach is safe and feasible in selected cases.
\end{abstract}

Keywords: Duodenum, Diverticula, Complications, Perforation, Surgical treatment

\section{Introduction}

The duodenum is the most common site for diverticula after the colon [1]. Duodenal diverticula, which can be single or multiple, are found in $5-10 \%$ of radiologic and endoscopic exams [2]. In over $70 \%$ of cases they are localized in the second portion of the duodenum, less frequently in the third or the fourth one, exceptionally in the first one $[2,3]$. They are usually asymptomatic; on the other hand they can determine abdominal postprandial pain, dyspeptic disorders or colic-like pains [2]; diverticulitis, bleeding, perforation may rarely occur $[4,5]$. The first case report of duodenal diverticulosis, describing a diverticulum containing 22 gallstones, was performed in 1710 by Chomel [6]. Surgery is necessary only if symptoms are

\footnotetext{
* Correspondence: veronicagrassi@hotmail.it

${ }^{1}$ General and Emergency Surgical Clinic. S. Maria Hospital, University of Perugia, Terni, Italy

${ }^{6}$ General and Emergency Surgical Clinic. S. Maria Hospital, University of Perugia, Via Tristano di Joannuccio 1, Terni, Italy

Full list of author information is available at the end of the article
}

persistent or if complications arise [7]: the diagnosis of perforated diverticula of the third duodenal portion is late and the management is still matter of debate [8-12]. In this techinal note we report a new sequential treatment of perforated duodenal diverticula.

\section{Case presentation}

Woman, 83 years old, emergency hospitalised for generalized abdominal pain. She reported some alimentary vomiting episodes and diarrheic bowel had occurred during the 3 days before admission and a history of colonic diverticular disease. In the physical examination globular abdomen and pain after deep palpation of the epi-mesogastric region were observed. Laboratory tests resulted within the normal range: leukocytes were $4720 / \mathrm{mm}^{3}$ (normal range $4500-10800 / \mathrm{mm}^{3}$ ), hematocrit was $50,5 \%$ (normal range $38-46 \%$ ), haemoglobin was $11.4 \mathrm{~g} / \mathrm{dl}$ (normal range $12-16 \mathrm{~g} / \mathrm{dl}$ ). The patient underwent plain abdominal X-Ray, which revealed neither free sub-diaphragmatic 
air nor air-fluid levels. Computed tomography (CT) scans, taken in emergency, showed a densitometric alteration in the periduodenal adipose tissue for the presence of multiple pools which extended along the right lateroconal fascia and occupied the anterior pararenal space, which includes the second and the third portion of the duodenum (Figure 1). At this exam a subtle perihepatic effusion layer was also detected. Within the third day from admission, after the onset of fever, leukocytosis, because of the increase of abdominal pain and the progressive clinical worsening a second abdominal CT scan was performed (Figure 2). This last radiological exam allowed to definitively exclude pneumoperitoneum; a wall herniation in the third portion of the duodenum containing endoluminal material and a breach in the medial wall of the same bowel segment were observed. Furthermore, contiguously to the duodenal breach, within the adipose tissue, in the context of an underlying fluid layer, air bubbles were detected. Being these findings strongly suggestive of a locally confined perforation, the patient in sepsis (temperature $39^{\circ} \mathrm{C}$, increased heart rate, leukocytes $16400 / \mathrm{mm}^{3}$ ) underwent emergency surgery. A partial coloepiploic detachment, Kocher manoeuvre to the proximal half of the II duodenal portion and subsequent isolation of the III one were performed; at this level, on the upper edge, a perforated diverticulum occupied the retroperitoneal space and it was partly surrounded by an abscess. The large implant base of the diverticulum prevented both the resection and the direct suture, being the laceration too jagged, thickened and oedematous (Figure 3). The septic condition of the patient prevented a derivation surgery, which would have been time consuming, demolitive and hazardous. A surgical toilette of abscess was performed passing through the

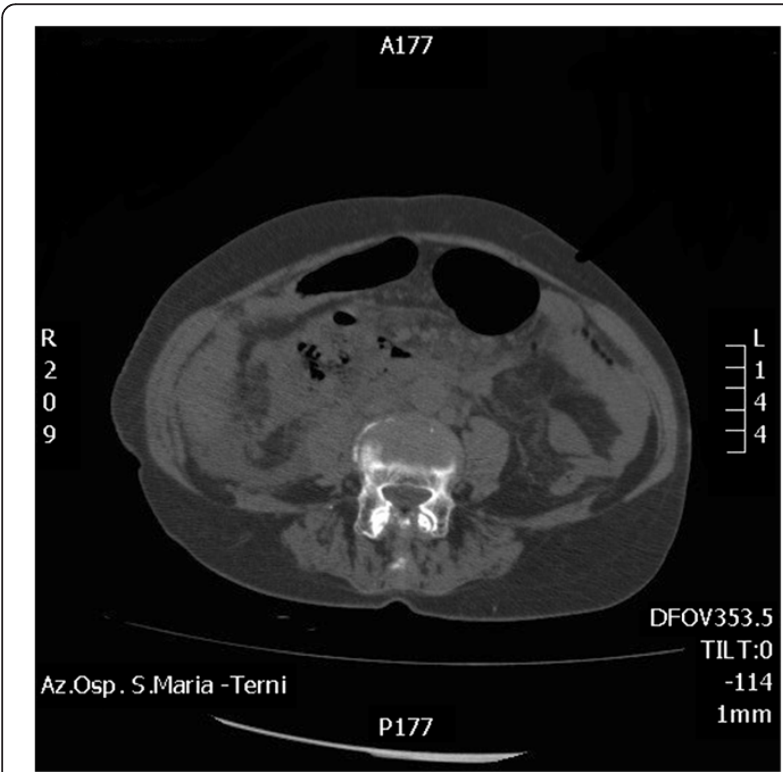

Figure $1 \mathrm{CT}$ on admission.

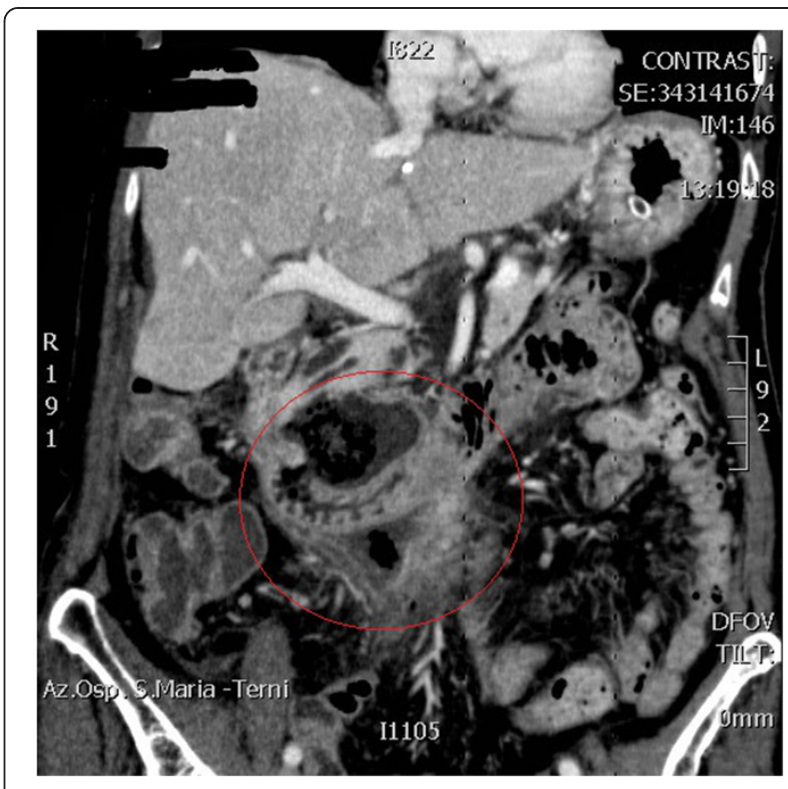

Figure 2 CT after three days from the admission.

perforated diverticula and the Petzer's tube drainage was placed in the duodenal lumen (Figure 4). On the first postoperative week the patient was fed with parenteral nutrition, on the second week the patient started a liquid diet and on the 15th post-operative day the patient got a solid diet. No postoperative complications occurred and the patient was discharged on the 30th post-operative day. The duodenostomic Petzer was endoscopically removed 4 months after the surgery. The Petzer's drainage tube was grasped by endoscopic transgastric way and then removed outside by oral way. In relation to the general condition of the patient was necessary to insert a nasogastric tube into the duodenum for 15 days to reduce the possibility of leak. During the procedure a nasogastric tube, previously anchored on the cutaneous edge of the Petzer, was pulled in the duodenum without effort, being the former on guide of the latter. A drainage tube was percutaneously positioned in the fistulous tract with its distal extremity outside the duodenum. Radiologic follow up with Gastrographin ${ }^{\circledR}$ confirmed the right position both of the nasogastric tube in the duodenum at the level of the fistulous orifice and of the drainage tube inside the tract, at about $4 \mathrm{~cm}$ from the wall of the duodenum. The drainage tube was left in place for 15 days (Figure 5). This procedure ensures less trauma and fewer potential complications in the subjects strongly debilitated. Fourteen days after, the patient underwent transit X-Ray with Gastromiro ${ }^{\circ}$ which showed a normal passage of the contrast medium without any sign of spillages or fistulous tracts. Check-up carried out after 12 months shows normal results.

\section{Discussion}

In our techinal note we reported a new surgical treatment of retroperitoneal abscess from diverticular perforation of 

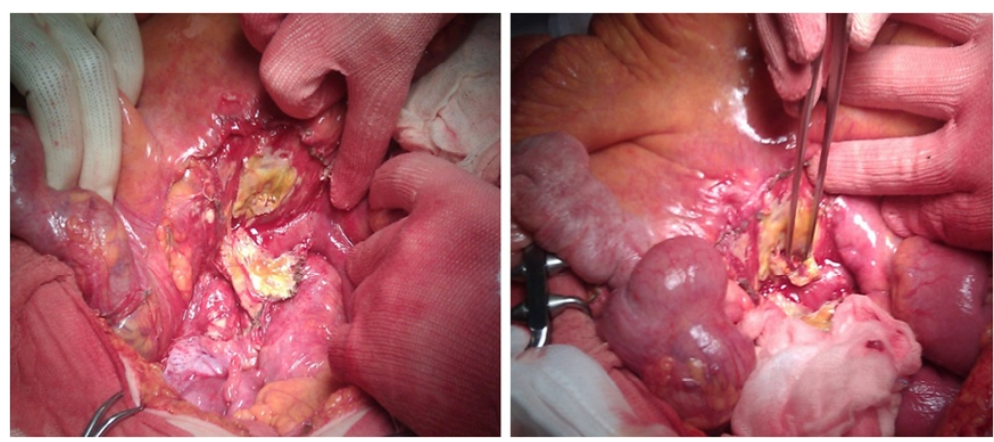

Figure 3 Intraoperative finding.

the III duodenal portion with endoscopic rendez-vous after damage control surgery. The advantage of this technique consists in performing a non-resective approach with no post operative complication rate. Duodenal diverticula located in the first portion have a low incidence; their site is on the anterior face or on the external right curve edge of the duodenum and their surgical management do not present remarkable technical difficulties. Duodenal diverticula are usually asymptomatic, surgery is needed in less than 3\% of cases [8], when clinical manifestations or complications are observed. In about $10 \%$ of cases duodenal diverticula are symptomatic (bleeding, pain and nausea caused by distension or inflammation) $[13,14]$ and they enter in the differential diagnosis of the acute abdomen [15-17]. Complications of duodenal diverticula are rare, but they could be devasting; the most frequent one is diverticulitis with perforation. Since diverticula of third portion are usually located in the retroperitoneal space, the onset of symptoms is often insidious and diagnosis is often delayed [18]. Even if several cases are described in which a conservative management with antibiotics and percutaneous drainage is preferred $[19,20]$, this treatment should be taken only after a careful consideration. In

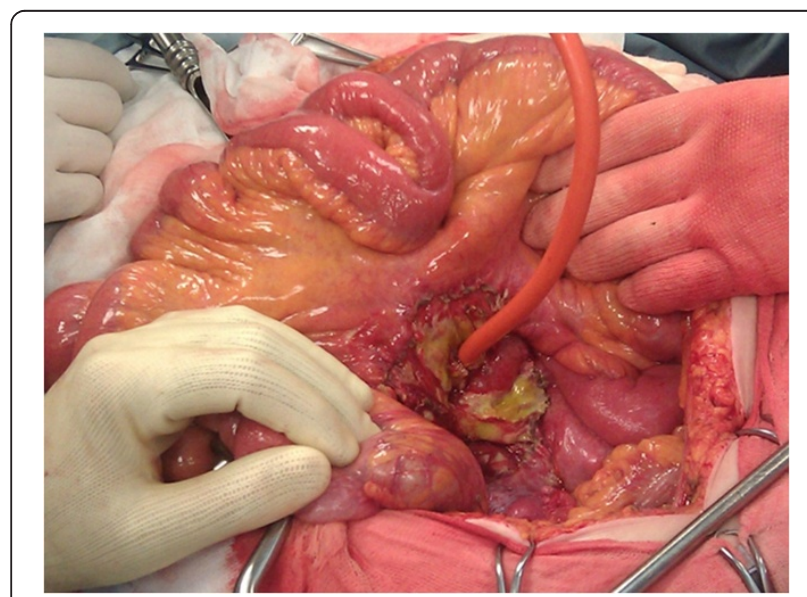

Figure 4 Petzer's tube drainage placement. literature, several types of treatments are described, both surgical or conservative, according to the patient's condition and the localization of the duodenal diverticulum: segmental duodenectomies, pylorus-preserving pancreaticoduodenectomy ( $\mathrm{p}-\mathrm{p}$ Whipple), diverticulectomies [11]. At the moment, the conventional treatment is diverticulectomy with duodenal closure and drainage positioning, especially when they are located in the retroperitoneal space [21-23]. The revision of the medical literature does not reveal any surgical treatment equal to ours for complicated diverticula in the third duodenal portion. A review of medical literature was performed; the research was restricted to studies published between September 1985 and December 2012. We reviewed 40 studies producing 64 cases. We considered the treatment of the perforated duodenal diverticulum; the results of this review was reported in Table 1. Perforations were most commonly located in the second ( $78 \%$ of cases) and in the third portion of the duodenum (17\% of cases). The most common approach is surgical (80\% of cases), although only few reports of conservative management with antibiotics and percutaneous drainage are available (3\% of cases). The indications to a surgical intervention and eventually the choice of the correct surgical

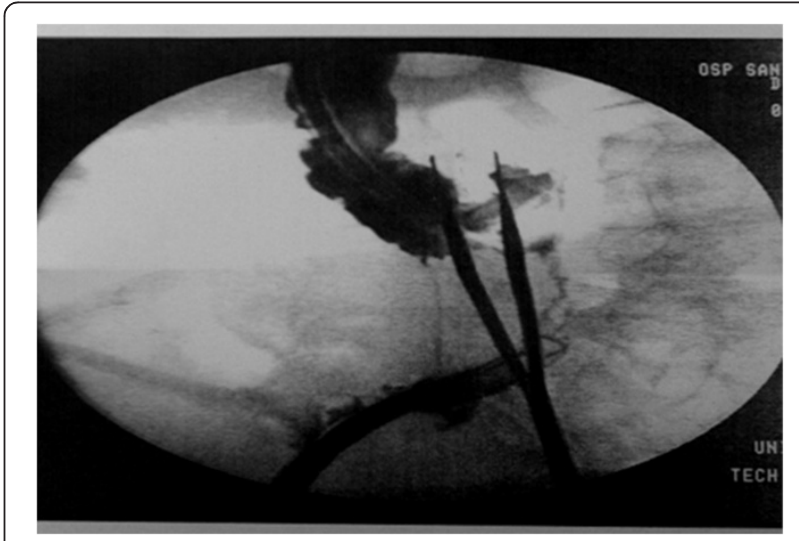

Figure 5 Nasogastric tube positioned in front of the diverticulum, anchored with a thread outside the drainage tube. 
Table 1 Kind of treatment of perforated duodenal diverticulum reported in medical literature

\begin{tabular}{|c|c|c|c|c|c|c|}
\hline \multirow[t]{2}{*}{ Author } & \multirow[t]{2}{*}{ Pz } & \multirow{2}{*}{$\begin{array}{l}\text { Duodenal } \\
\text { portion }\end{array}$} & \multirow[t]{2}{*}{ Year } & \multirow{2}{*}{$\begin{array}{l}\text { Kind of treatment } \\
\text { performed }\end{array}$} & \multicolumn{2}{|c|}{ Type of treatment } \\
\hline & & & & & Surgical & Non-surgical \\
\hline Thorson CM et al. [11] & 4 & II portion & 2012 & Non operative management & & Bowel rest antibiotics \\
\hline Metcalfe MJ et al. [24] & 1 & II portion & 2010 & Surgical treatment & Diverticulectomy & \\
\hline Gottschalk U et al. [25] & 1 & II portion & 2010 & Endoscopical treatment & & \\
\hline Lee HH et al. [23] & 1 & II portion & 2010 & Surgical treatment & Laparoscopic Diverticulectomy & \\
\hline Volchok J et al. [26] & 1 & II portion & 2009 & Surgical treatment & Diverticulectomy & \\
\hline Lopez-Zarraga F et al. [27] & 1 & II portion & 2009 & Surgical treatment & Diverticulectomy & \\
\hline Ames JT et al. [28] & 8 & $\begin{array}{l}\text { Il portion } \\
\text { III portion }\end{array}$ & 2009 & $\begin{array}{l}\text { Surgical treatment and } \\
\text { nonoperative management }\end{array}$ & $N R$ & Bowel rest antibiotics \\
\hline Guinier D et al. [29] & 1 & II portion & 2008 & Surgical treatment & Diverticulectomy & $N R$ \\
\hline \multirow[t]{3}{*}{ Schnueriger B et al. [10] } & 5 & $\begin{array}{l}\text { II Portion } \\
\text { III Portion }\end{array}$ & 2008 & $\begin{array}{l}\text { Surgical treatment and } \\
\text { nonoperative management }\end{array}$ & -Segmental duodenectomy & $\begin{array}{l}\text { PTC tube, Bowel rest, } \\
\text { Antibiotics }\end{array}$ \\
\hline & & IV Portion & & & $\begin{array}{l}\text {-Pylorus-preserving duodeno- } \\
\text { pancreatectomy (pp-Whipple) }\end{array}$ & \\
\hline & & & & & -Diverticulectomy & \\
\hline $\begin{array}{l}\text { Martinez-Cecilia D } \\
\text { et al. [19] }\end{array}$ & 1 & II Portion & 2008 & Conservative treatment & $N R$ & $\begin{array}{l}\text { Bowel Rest, Antibiotics } \\
\text { and percutaneous drainage }\end{array}$ \\
\hline Huang RY et al. [20] & 1 & II Portion & 2007 & Surgical treatment & Diverticulectomy & $N R$ \\
\hline Hirota S et al. [30] & 1 & II portion & 2007 & Surgical treatment & $N R$ & $N R$ \\
\hline $\begin{array}{l}\text { Andromanakos N } \\
\text { et al. [31] }\end{array}$ & 1 & II Portion & 2007 & Surgical treatment & $\begin{array}{l}\text { Subtotal gastrectomy and antecolic } \\
\text { anastomosis and retroperitoneal } \\
\text { drainage }\end{array}$ & $N R$ \\
\hline $\begin{array}{l}\text { Valenzuela Martínez MJ } \\
\text { et al. [32] }\end{array}$ & 1 & II Portion & 2006 & Surgical treatment & Diverticulectomy & \\
\hline Safioleas M et al. [33] & 1 & II portion & 2006 & Surgical treatment & Gastrojejunostomy, drenage & \\
\hline Castellví J et al. [34] & 1 & III Portion & 2006 & Surgical treatment & $\begin{array}{l}\text { Gastroenteroanastomosis and } \\
\text { biliary drainage with Kehr, } \\
\text { gastrojejunostomy }\end{array}$ & $N R$ \\
\hline Miller G et al. [8] & 3 & $\begin{array}{l}\text { II Portion } \\
\text { III Portion }\end{array}$ & 2005 & $\begin{array}{l}\text { Surgical treatment and } \\
\text { nonoperative management }\end{array}$ & $\begin{array}{l}\text { Diverticulectomy, diversion } \\
\text { (pyloric exclusion, } \\
\text { gastrojejunostomy) }\end{array}$ & Antibiotics, bowel rest \\
\hline Papalambros E et al. [35] & 1 & III Portion & 2005 & Surgical treatment & $\begin{array}{l}\text { Diverticulectomy and duodenostomy } \\
\text { at the second duodenal portion }\end{array}$ & \\
\hline Lee VT et al. [36] & 1 & II Portion & 2005 & Surgical treatment & Roux -en- Y duodenojejunostomy. & \\
\hline Bergman S et al. [22] & 1 & II portion & 2005 & Surgical treatment & Diverticulectomy and duodenotomy & \\
\hline Marhin WW et al. [37] & 2 & II portion & 2005 & $\begin{array}{l}\text { Surgical and conservative } \\
\text { treatment }\end{array}$ & Diverticulectomy & Antibiotics therapy \\
\hline Yokomuro S et al. [7] & 1 & II portion & 2004 & Surgical treatment & Primary closure with drainage & \\
\hline Sakurai Y et al. [6] & 1 & II portion & 2004 & Surgical treatment & Diverticulectomy & \\
\hline Yarze JC et al. [38] & 1 & II portion & 2002 & Surgical treatment & Diverticulectomy & \\
\hline Franzen D et al. [16] & 1 & II portion & 2002 & Surgical treatment & Diverticulectomy & \\
\hline Atmani A et al. [39] & 2 & II portion & 2002 & Surgical treatment & $\begin{array}{l}\text { Diverticulectomy lateral } \\
\text { duodenostomy, T tube }\end{array}$ & \\
\hline Gulotta G et al. [40] & 1 & II portion & 2001 & Surgical treatment & $\begin{array}{l}\text { Diverticulo-jejunostomy on a } \\
\text { Roux-en-Y }\end{array}$ & \\
\hline Eeckhout G et al. [41] & 1 & II portion & 2000 & $\begin{array}{l}\text { Percutaneous and endoscopic } \\
\text { management }\end{array}$ & & \\
\hline
\end{tabular}




\section{Table 1 Kind of treatment of perforated duodenal diverticulum reported in medical literature (Continued)}

\begin{tabular}{|c|c|c|c|c|c|c|}
\hline Tsukamoto T et al. [42] & 2 & II portion & 1999 & $\begin{array}{l}\text { Surgical treatment and } \\
\text { nonoperative management }\end{array}$ & Diverticulectomy & $\begin{array}{l}\text { Antibiotics, percutaneous } \\
\text { abscess drainage. }\end{array}$ \\
\hline Rao PM et al. [15] & 1 & III portion & 1999 & Surgical treatment & $N R$ & \\
\hline Poostizadeh A et al. [43] & 1 & III portion & 1997 & Surgical treatment & Diverticulectomy, Gastrostomy & \\
\hline Ido K et al. [44] & 1 & II portion & 1997 & Surgical treatment & Diverticulectomy & \\
\hline Cavanagh JE et al. [45] & 1 & II portion & 1996 & Surgical treatment & Malecot drainage in diverticulum & \\
\hline Mehdi A et al. [46] & 2 & $\begin{array}{l}\text { I| portion } \\
\text { III portion }\end{array}$ & 1994 & Surgical treatment & Diverticulectomy & \\
\hline Guglielmi A et al. [47] & 2 & II portion & 1993 & Surgical treatment & Diverticuletomy, diversion & \\
\hline Pugash RA et al. [48] & 2 & II portion & 1990 & Surgical treatment & Aspiration, drainage, $T$ tube & \\
\hline Steinman E et al. [49] & 2 & $\begin{array}{l}\text { Il portion } \\
\text { IIl portion }\end{array}$ & 1989 & Surgical treatment & Drainage & \\
\hline Beech RR et al. [50] & 1 & II portion & 1985 & Surgical treatment & Tube duodenostomy & \\
\hline Stebbings WS et al. [51] & 2 & I portion & 1985 & Surgical treatment & $\begin{array}{l}\text { Diverticuletomy, primary closure } \\
\text { with drainage }\end{array}$ & \\
\hline
\end{tabular}

approach, depend on the patient's clinical situation and intraoperative findings. If the inflammation didn't severely impair the access to the interested structures and their integrity, the treatment of choice is, after Kocher manoeuvre, diverticulectomy with single or double-layer duodenal closure (45\% of cases). It is important to place drainage tubes, especially in the retroperitoneum, if affected. A slice of the greater omentum can be patched over the closure. Injury to the pancreatic or distal common bile duct can be avoided by placing a tube into the ampulla of Vater before dissecting the diverticulum. When there is substantial inflammation of the duodenum, a diversion should be performed by a subtotal gastrectomy followed by Billroth II reconstruction, or a Roux-en-Y gastroenteroanastomosis (12\% of cases). Only patients with mild disease are likely to benefit from nonoperative management. In the case described above, the demolition of the duodeno-cephalo-pancreatic region, as well as the confectioning of a bilio-digestive anastomosis of hepatic type or a choledochal jejunostomy for bypass purpose, were not affordable because of the septic conditions caused by the purulent peritonitis. Our treatment, to our knowledge, has never been described, and we propose it as a new and innovative treatment for partients whose general conditions do not allow demolitive invasive surgery.

\section{Conclusion}

Our two-stage technique consisting in damage control surgery and endoscopic review enabled us to treat a patient with retroperitoneal abscess from the third portion of the duodenum for which a more demolishing surgical procedure was not recommended. This method implies a close multidisciplinary relation between the surgeon, the endoscopist and the interventional radiologist.

\section{Consent}

Written informed consent was obtained from the patient for publication of this Case report and any accompanying images. A copy of the written consent is available for review by the Editor-in-Chief of this journal.

\section{Abbreviation \\ $\mathrm{CT}$ : Computed tomography.}

\section{Competing interests}

The authors declare that they have no competing interests.

\section{Authors' contributions}

$R C, A D, I B, A C$ were involved in pre-operative diagnosis and postoperative care. RC and CB conceived the study and participated in the design of the study. IB and VG wrote the manuscript. CR and FB participated in preparation of the figures. AC, LC, AP, GC helped in literature research and critically revised the manuscript. RC and GN coordinated the study. All authors contributed and approved the final version of the manuscript.

\section{Author details}

${ }^{1}$ General and Emergency Surgical Clinic. S. Maria Hospital, University of Perugia, Terni, Italy. ${ }^{2}$ General and Oncological Surgical Clinic. S. Maria della Misericordia, University of Perugia, Perugia, Italy. ${ }^{3}$ Urological Andrological Surgery and Minimally Invasive Techniques. S. Maria Hospital, University of Perugia, Terni, Italy. ${ }^{4}$ General Surgical Clinic. S. Maria della Misericordia, Perugia, Italy. ${ }^{5}$ Thoracic Surgery Unit. S. Maria della Misericordia, University of Perugia, Perugia, Italy. ${ }^{6}$ General and Emergency Surgical Clinic. S. Maria Hospital, University of Perugia, Via Tristano di Joannuccio 1, Terni, Italy.

Received: 2 March 2013 Accepted: 7 June 2013

Published: 16 July 2013

\section{References}

1. Knoefel WT, Rattner DW: Duodenal diverticula and duodenal tumours, 1 In Oxford Text Book of Surgery. Edited by Morris PJ, Malt RA. New York: Oxford University Press; 1994:943-946.

2. Evers BM: Small intestine. In Sabiston textbook of surgery: the biological basis of modern surgical practice. 18th edition. Edited by Townsend CM, Beauchamp RD, Evers BM, Mattox KL. Philadelphia: WB Saunders Company; 2008:1318-1319. 
3. Dionigi R, Mosca F, Dominioni L, Dionigi G: Stomaco e duodeno. In Chirurgia: basi teoriche e chirurgia generale. 3rd edition. Edited by Dionigi R. Milano: Elsevier Masson; 2002:503.

4. Evers BM, Townsend CM, Thompson JC: Small intestine. In Schwartz's principles of surgery. 7th edition. Edited by Shwartz SI, Shires GT, Spencer FC, Daly JM, Fischer JE, Galloway AC. New York: MCGraw-Hill; 1999:1247.

5. Chomel JB: Report of a case of duodenal diverticulum containing gallstones. Histoire Acad R Sci Paris 1710:48-50

6. Sakurai Y, Miura H, Matsubara T, et al: Perforated duodenal diverticulum successfully diagnosed preoperatively with abdominal CT scan associated with upper gastrointestinal series. J Gastroenterol 2004, 39:379-383.

7. Yokomuro S, Uchida $E$, Arima $Y$, et al: Simple closure of a perforated duodenal diverticulum: "a case report". J Nihon Med Sch 2004, 71:337-339.

8. Miller G, Mueller C, Yim D, et al: Perforated duodenal diverticulitis: a report of three cases. Dig Surg 2005, 22:198-202.

9. Chen CF, Wu DC, Chen CW, et al: Successful management of perforated duodenal diverticulitis with intra-abdominal drainage and feeding jejunostomy: a case report and literature review. Kaohsiung J Med Sci 2008 24:425-429

10. Schnueriger B, Vorburger SA, Banz VM, et al: Diagnosis and management of the symptomatic duodenal diverticulum: a case series and a short review of the literature. J Gastrointest Surg 2008, 12:1571-1576.

11. Thorson CM, Paz Ruiz PS, Roeder RA, et al: The perforated duodenal diverticulum. Arch Surg 2012, 147:81-88.

12. Lida F: Transduodenal diverticulectomy for periampullar diverticula. World J Surg 1979, 3(103-6):135-136.

13. Pearl MS, Hill MC, Zeman RK: CT findings in duodenal diverticulitis. AJR Am J Roentgenol 2006, 187:392-395.

14. Donald JW: Major complications of small bowel diverticula. Ann Surg 1979, 190:183-188.

15. Rao PM: Case 11: perforated duodenal diverticulitis. Radiology 1999, 211:711-713.

16. Franzen D, Gürtler T, Metzger U: Solitary duodenal diverticulum with enterolith as a rare cause of acute abdomen. Swiss Surg 2002, 8:277-279.

17. Miller RE, McCabe RE, Salomon PF, Knox WG: Surgical complications of small bowel diverticula exclusive of Meckel's. Ann Surg 1970, 171:202-210.

18. Van Beers B, Trigaux JP, De Ronde T, Melange M: CT findings of perforated duodenal diverticulitis. J Comput Assist Tomogr 1989, 13:528-530.

19. Martinez-Cecilia D, Arjona-Sanchez A, Gomez-Alvarez M, et al: Conservative management of perforated duodenal diverticulum: a case report and review of the literature. World J Gastroenterol 2008, 14:1949-1951.

20. Huang RY, Romano AE, Stone ME, Nathanson N: Diagnosis and treatment of a perforated duodenal diverticulum. Emerg Radiol 2007, 13:285-287.

21. Lotveit T, Skar V, Osnes M: Juxtapapillary duodenal diverticula. Endoscopy 1988, 20:175-178.

22. Bergman S, Koumanis J, Stein LA, et al: Duodenal diverticulum with retroperitoneal perforation. Can J Surg 2005, 48:332

23. Lee HH, Hong JY, Oh SN, et al: Laparoscopic diverticulectomy for a perforated duodenal diverticulum: a case report. J Laparoendosc Adv Surg Tech A 2010, 20:757-760

24. Metcalfe MJ, Rashid TG, Bird RR: Isolated perforation of a duodenal diverticulum following blunt abdominal trauma. J Emerg Trauma Shock. 2010, 3:79-81.

25. Gottschalk U, Becker C, Stöhr M, et al: Duodenal diverticulum-a therapeutic challenge. Gastroenterol. 2010, 48:551-554

26. Volchok J, Massimi T, Wilkins S, et al: Duodenal diverticulum: case report of a perforated extraluminal diverticulum containing ectopic pancreatic tissue. Arch Surg 2009, 144:188-190.

27. López Zárraga F, Saenz De Ormijana J, Diez Orive M, et al: Abdominal pain in a young woman. Eur Radio/ 2009, 19:2783-2786. Nov.

28. Ames JT, Federle MP, Pealer KM: Perforated duodenal diverticulum: clinical and imaging findings in eight patients. Abdom Imaging 2009, 34:135-139. Mar-Apr.

29. Guinier D, Kovacs R: Spontaneous perforation of a retroperitoneal duodenal diverticulum. J Chir (Paris) 2008, 145:287-288. May-Jun

30. Hirota S, Tsujikawa T, Kitoh K, et al: An elderly woman with duodenal perforation difficulty diagnose. Nihon Ronen Igakkai Zasshi 2007, 44:752-755.

31. Andromanakos N, Filippou D, Skandalakis $P$, et al: An extended retroperitoneal abscess caused by duodenal diverticulum perforation: report of a case and short review of the literature. Am Surg 2007, 73:85-88.

32. Valenzuela Martínez MJ, Bonasa E, Sánchez JM, et al: Traumatic perforation of a duodenal diverticulum. Cir Esp 2006, 80:224-226.

33. Safioleas M, Stamatakos MK, Mouzopoulos GJ, et al: Pancreatic abscess due to perforation of duodenal diverticulum. Chirurgia (Bucur) 2006, 101:523-524. Sep-Oct.

34. Castellví J, Pozuelo O, Vallet J, et al: Perforated duodenal diverticulum. Cir Esp 2006, 80:174-175.

35. Papalambros E, Felekouras E, Sigala F, et al: Retroperitoneal perforation of a duodenal diverticulum with colonic necrosis - report of a case. Zentralbl Chir 2005, 130:270-273.

36. Lee VT, Chung AY, Soo KC: Mucosal repair of posterior perforation of duodenal diverticulitis using roux loop duodenojejunostomy. Asian J Surg 2005, 28:139-141.

37. Marhin WW, Amson BJ: Management of perforated duodenal diverticula. Can J Surg 2005, 48:79-80.

38. Yarze JC: Duodenoscopic diagnosis of perforated periampullary diverticulitis. Am J Gastroenterol 2002, 97:769.

39. Atmani A, Lachachi F, Sodji M, et al: Perforated juxta-papillary duodenal diverticula: two cases. Gastroenterol Clin Biol 2002, 26:285-288.

40. Gulotta G, Agosta G, Romano G: Perforated duodenal diverticulum: report of a case. Chir Ital 2001, 53:255-258. Jan-Feb.

41. Eeckhout G, Vanstiphout J, Van Pottelbergh I, et al: Endoscopic treatment of a perforated duodenal diverticulum. Endoscopy 2000, 32:991-993.

42. Tsukamoto $T$, Ohta $Y$, Hamba $H$, et al: Perforated duodenal diverticulum: report of two cases. Hepatogastroenterology 1999, 46:1755-1758. May-Jun.

43. Poostizadeh A, Gow KW, Al-Mahmeed T, et al: Traumatic perforation of duodenal diverticulum. J Trauma 1997, 43:370-371.

44. Ido K, Agata H, Toshimitsu K, et al: Preoperative diagnosis of perforated duodenal diverticulum with ultrasonography. Clin Ultrasound 1997 25:149-153. Mar-Apr.

45. Cavanagh JE Jr: latrogenic perforation of perivaterian duodenal diverticulum: report of a case. Can J Surg 1996, 39:336-338.

46. Mehdi A, Closset J, Houben JJ, et al: Duodenal diverticula--diagnosis and management of complicated forms: report of two clinical cases and review of the literature. Acta Chir Belg 1994, 94:311-313. Nov-Dec.

47. Guglielmi A, Veraldi GF, Leopardi F, et al: The perforation of a para-Vater's duodenal diverticulum (a report of 2 clinical cases) Ann Ital Chir. MayJun; 1993, 64:309-312. discussion 313

48. Pugash RA, O'Brien SE, Stevenson GW: Perforating duodenal diverticulitis. Gastrointest Radiol 1990, 15:156-158.

49. Steinman E, Utiyama EM, Bevilacqua RG, et al: [Perforated duodenal diverticulum: a report of 2 cases]. Rev Hosp Clin Fac Med Sao Paulo 1989, 44:121-123. May-Jun.

50. Beech RR, Friesen DL, Shield CF: Perforated duodenal diverticulum: treatment by tube duodenostomy. Curr Surg 1985, 42:462-465. Nov-Dec.

51. Stebbings WS, Thomson JP: Perforated duodenal diverticulum: a report of two cases. Postgrad Med J 1985, 61:839-840.

doi:10.1186/1749-7922-8-26

Cite this article as: Barillaro et al:: Endoscopic rendez-vous after damage control surgery in treatment of retroperitoneal abscess from perforated duodenal diverticulum: a techinal note and literature review. World Journal of Emergency Surgery 2013 8:26.

\section{Submit your next manuscript to BioMed Central and take full advantage of:}

- Convenient online submission

- Thorough peer review

- No space constraints or color figure charges

- Immediate publication on acceptance

- Inclusion in PubMed, CAS, Scopus and Google Scholar

- Research which is freely available for redistribution 